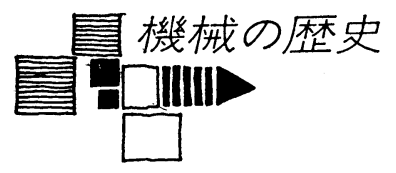

\section{ホイヘンスの振子時計と 巻きヒゲゼンマイ付時計}

(株)第二精工舎 久保田 浩 司

17 世紀は，科学革命時代と表現されるぐらい目まぐ るしい変化のきざしを見せる科学の夜明けの時代であっ た．当時，ホイヘンス (C. Huygens, 1629-1695) の置か れている位置もまたいろいろな意味で重要である.

彼の研究でだれでもが知っているのは, 光の波動説や 自製の屈折望遠鏡による土星の衛星環の発見などであ る.そして彼は時計の分野でも二つの大きな発明をなし とげている.

振子時計については，1581 年ガリレイは 17 歳のとき 振子の等時性を発見し，1641 年にそれを時計の調速機と して用いることを着想した，不完全ながらも実際の時計

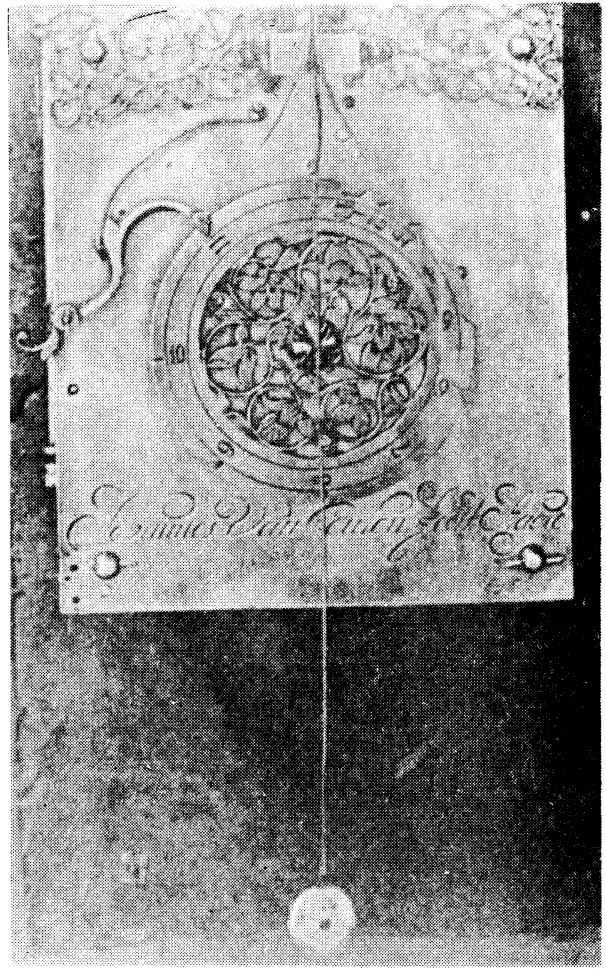

図 1 ホイヘンスの振子時計 (ライフ編集部編：時の話，タ イム・ライフインターナショナル)
になったのは 1649 年であり, 息子の Vicenzio の手で作 られたと伝えられている。

しかし，ホイヘンスは,ガリレイが考えた単振子では, 振幅が大きくなると䛊差が大きくなることを発見した。

そこでホイヘンスは時計師の手を借りて，振子を 2 本 のひもでつり，そのひもの取付部の両脇を板金ではさん た時計を発明した（図 1 参照)。振子が振れると，ひも はその板金につけられたカーブに沿って曲がり，振子の 重心運動はサイクロイド曲線上を動き，振幅とは関係な く等時性が得られる.この時計は 1657 年, オランダ議会 飞備え付けられた。

その後ホイヘンスは，この原理がガリレイのそれとは 違うということで, 翌年の 1658 年の小論文及び 1673 年 の有名は論文「振子時計」(Horologium Oscillatorium) を発表し，時計理論の先駆的役割を果たした。

彼のもら一つの大きな仕事としては，卷きヒゲゼンマ イの時計への適用がある．直線ヒゲゼンマイを時計に用

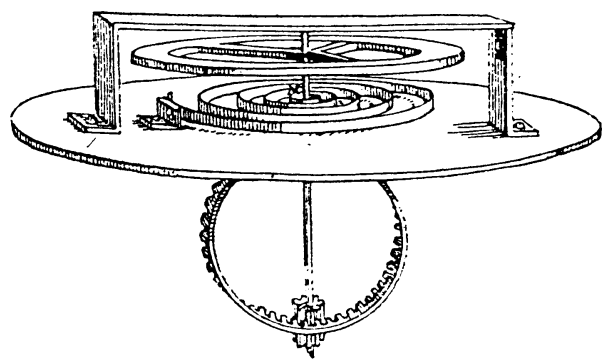

図 2 ホイヘンスの巻きヒゲゼンマイ (Tardy: La Montre, Tardy)

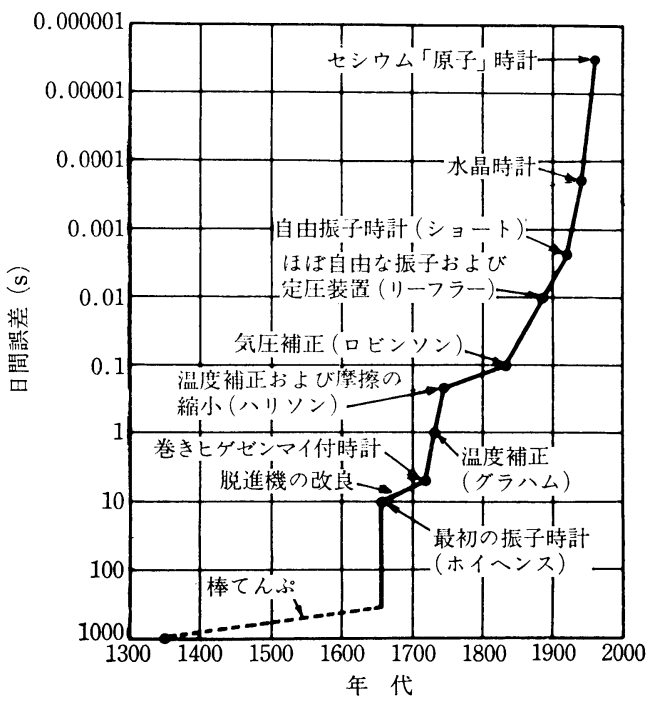

図 3 時計の精度向上の推移 (C.M. チポラ (党石敬一訳)： 時計と文化，みすず書房） 
いることは「フックの法則」で有名な R. Hooke が 1660 年権利化し，1664 年の講演の中でも発表している.とこ ろが，その後ホイヘンスは，「ゼンマイがうずまき状を している時計」に関する資料を 1674 年 7 月 7 日, 王立科 学アカデミーに提出した. 彼はこの中で, このゼンマイ がフックの直線ヒゲとは異なることを示唆している.

図 2 の時計は,ルイ 14 世御抱えの時計師 Thuretによ り製作され，1675 年 1 月 22 日に発表されたものである.

以上 2 点の発明は，それまで「時針 1 本であった時計 に分針を付けた」と言われるぐらい時計の精度を上げ た. 振子はクロックの, 巻きヒゲゼンマイはウオッチの 振動子として以後 300 年の時計の基礎的要素となったと いらことは十分評価されてよいことである.

終わりに，時計の精度がどのように高くなってきたか
といらことを参考までに図 3 に示しておく．

（原稿受付 昭和 54 年 7 月 2 日）

\section{一本欄に掲載する原稿の募集について}

“機械の歷史”欄のために, 下記要綱により広く原稿を募 集いたします．この闌の充実・継続のために，多くの方及 がご寄稿くださいますようお願い申しあげます.

1. 内 容 歴史上の機器についての原理, 構造, 仕 様, 特長等についての解説記事.

2. 原稿枚数 400 字詰原稿用紙 3 枚と図または写真 2 枚前後（刷上がり 1 ページ).

3. ご寄稿いただいた原稿の採否は会誌編集委員会にご 一任ください，なお，場合によっては内容について 照会することもありますので，あらかじめご了承く ださい，また，掲載分については，わずかですが稿 料をお送りします。

\begin{tabular}{ll}
\hline 情 \\
\hline
\end{tabular}

\section{低周波空気振動の防止策}

環境庁はこのほど低周波空気振動㛑急防止対策の調査 結果をまとめ，発表した。

これは，低周波空気振動に起因すると考えられる苦情 が増えているのに対処して, 同庁が小林理学研究所に委 託，産業用機械から発生する低周波空気振動を対象に取 り上げ,現在行われている対策法をまとめたものである.

主な内容は，(1) 産業用機械による発生源をみると王縮 機（機能的にはポンプも含む）および送風機のように空 気流を伴らものが半数以上を占める，(2) 低周波空気振動 の対策は騒学・振動々同様に発生源でとら光対処するこ とが望ましい一一などをあげている。

同庁はこの調查報告書を全国都道府県に配布して防止 対策の参考に役立てる一方，引き続いて低周波空気振動 についての調査を進め, 57 年度以降の環境基準設定の可 能性などを検討する.

主な調查結果は次のと和り。

1. 産業用機械における低周波空気振動発生源二産業 用機械，つまり工場機械をみると，その発生源は次のよ
らに分類できる.

(1)板の振動による発生源＝大型の振動ふるいとか, 振 動コンベアのように，ある面積をもったものが平行運動 をすると，大型スピーカのように音を出すことが模擬的 に考えられる. また工場建屋の壁体のような大きな面積 が運動すれば，面積をもつ発生源となり得る。

(2)流れによる発生源=送風機で大量の空気を吸引また は押し込む場合, 強制力と実移動量とのアンバランス, 空気力学的ならずの発生などにより圧力変動を生じ, 低 周波空気振動の発生源となる.

(3)燃焼による発生源二燃焼装置では, 燃料の噴出機構 と送風装置が組合わされているものが大部分だから, 非 定常的な燃焼状態では, 気圧変動を生じ, 低周波空気振 動の発生源となる.

(4)その他二往復動型の圧縮機や真空ポンプなど容積変 動による発生源とか，配管による発生源がある．低周波 空気振動の発生機構の解明は対策検討のための重要な一 要素である. (p. 508 へ続く) 